\title{
Fruit biometry and seed germination of Syagrus romanzoffiana (Cham.) Glassm.
}

Flora Goudel ${ }^{1}$, Marília Shibata², Cileide Maria Medeiros Coelho ${ }^{3}$ and Paul Richard Momsen Miller ${ }^{4}$

Submitted: 16 July, 2012. Accepted: 11 November, 2012.

\begin{abstract}
Syagrus romanzoffiana (Cham.) Glassm. is a species native to Brazil that is of ecological and aesthetic importance. This study aims to describe the biometric characteristics of $S$. romanzoffiana fruits and to assess the effects that treatments meant to overcome dormancy and partial drying have on seed germination. For biometric characterization, each repetition consisted of 50 fruits from eight clusters (total, 400 fruits). To evaluate methods for overcoming dormancy, seeds representative of populations were treated by perforation of the operculum; perforation of the operculum and immersion in water for 24 hours; cracking; exposure to fire for three minutes; and non-removal of fibers. There was also a control group. In a second experiment, seeds were partially dried. We determined the proportional moisture content of newly harvested seeds (20.2\%) and dried them down to moisture contents of $15.5 \%$ and $12.7 \%$. All seeds were subjected to a germination test at $30^{\circ} \mathrm{C}$. The fruits showed biometric variations, with an average of $21.7 \mathrm{~mm}$ in longitudinal diameter and $19.7 \mathrm{~mm}$ in polar diameter, and a fresh mass of $5.61 \mathrm{~g}$, of which $59.29 \%$ was pulp. The highest germination rates and vigor to overcome dormancy occurred after the operculum was perforated and the seeds were soaked in water for 24 hours. The results of the partial drying treatments did not differ sufficiently to discourage dormancy in any significant manner.
\end{abstract}

Key words: dormancy; Syagrus romanzoffiana; palm; drying; variability

\section{Introduction}

Syagrus romanzoffiana (Arecaceae, common name: jerivá) is a palm native to Brazil that is distributed along the entire coast, from the state of Ceara to the state of Rio Grande do Sul, as well as in the inland areas of the states of Minas Gerais, Goiás and Mato Grosso do Sul (Lorenzi 2002). In the state of Santa Catarina, it shows significant distribution, its presence beginning in the coastal restinga (shrublands) and continuing to mixed rain forest and dense rain forest, as well as to the fields and seasonal deciduous forests of the extreme west, which shows its wide ecological amplitude (Reitz 1974). The ecological and geographic plasticity of $S$. romanzoffiana can result in adaptive genetic variation of populations that have evolved in different habitats, and there may be varieties that are better adapted to certain soil and climatic conditions.

Fruit biometrics is an instrument used to examine the genetic variability within populations of the same species and the relationship between this variability and environ- mental factors (Macedo et al. 2009), as well as offer assistance for the differentiation of species of the same genus (Cruz et al. 2001) and the identification of varieties for breeding projects.

Studies dealing with agronomic traits, such as the physical characteristics of fruit, are necessary for understanding the productive capacity of a species (Schwartz et al. 2010). Parameters such as the proportion of pulp, endocarp and seed constitute basic information that indicates the productive and economic potential of the fruit as a food resource or as raw material in the manufacture of cosmetics, pharmaceuticals or herbal medicines. However, there is a dearth of information about the biometric parameters of the fruit and seeds of S. romanzoffiana. Some characteristics have been described in isolation: an ovoid drupe, measuring approximately $2-3 \mathrm{~cm}$ in length and 1-2 cm in diameter (Reitz 1974; Genini et al. 2009); fruit with sweet and fleshy pulp, yellow-orange when ripe (Reitz 1974; Genini et al. 2009); and a seed weight of 0.5 g (Balick 1979).

\footnotetext{
${ }^{1}$ Universidade Federal de Santa Catarina, Programa de Pós-Graduação em Agroecossistemas, Lages, SC, Brazil

${ }^{2}$ Universidade Federal de Santa Catarina, Programa de Pós-Graduação em Recursos Genéticos Vegetais, Lages, SC, Brazil

${ }^{3}$ Universidade do Estado de Santa Catarina, Centro de Ciências Agroveterinárias, Departamento Agronomia, Lages, SC, Brazil

${ }^{4}$ Universidade Federal de Santa Catarina, Centro de Ciências Agrárias, Departamento de Engenharia Rural, Lages, SC, Brazil

${ }^{5}$ Author for correspondence: floragoudel@hotmail.com
} 
Currently, the species is widely used as an ornamental plant, not only for its beauty, but also for the ease with which it can be transplanted, even when fully grown. It is widely used in the landscaping of Brazil (Lorenzi 2002) and in other tropical and subtropical regions, in Asia (Lam et al. 2008) and the Mediterranean, as well as in the United States, where it is known as the queen palm (Downer \& Hodel 2001).

Knowledge of the germination of forest seeds is important, because it facilitates projects related to regeneration, forestry, conservation and utilization of genetic resources (Cruz \& Carvalho 2002). The main propagation method of S. romanzoffiana is sexual: its seeds have an average germination rate and a low speed of emergence, which suggests the existence of some mechanism of dormancy (Carvalho 2006). For seedling production, this mechanism is a disadvantage, as it induces great non-uniformity in seedling emergence and seed loss due to deterioration, because seeds remain in the soil longer before germination (Smiderle et al. 2005).

The palm seeds generally show recalcitrant behaviorthey do not tolerate being dried to a low water content or stored at low temperature-and loss of viability occurs within weeks or months (Broschat 1994). However, Torres (2002) reported that the amount of water present in the seeds of $S$. romanzoffiana is lower than in other species of this family, such as, for example, Euterpe oleracea and Dypsis lutescens, which have a moisture content of $40 \%$ and $35 \%$, respectively (Martins et al. 1999a; Negreiros \& Perez 2004). Partial drying of seeds with recalcitrant behavior can contribute to the preservation thereof. Bilia et al. (1998) found that reducing the moisture content from $58 \%$ to $49 \%$ allowed for the preservation of physiological potential in the storage of Inga uruguensis seeds.

Given the abovementioned facts, this study aims to describe the biometric parameters of $S$. romanzoffiana fruit, to evaluate treatments to overcome dormancy and to determine the effect that partial seed drying has on viability and vigor of $S$. romanzoffiana seeds.

\section{Materials and methods}

\section{Fruit biometrics}

Mature fruits from eight bunches of $S$. romanzoffiana (Cham.) Glassm. were harvested and separated into samples of 50 healthy fruits selected at random from the base, middle and apex of each cluster (Moura et al. 2010), totaling 400 fruits. Samples were labeled and stored under refrigeration $\left(5 \pm 1^{\circ} \mathrm{C}\right)$ until measurements were taken.

Values were measured and averages calculated for the following characteristics (Moura et al. 2010): fresh mass of the fruit; fresh mass, dry mass and moisture of the pulp (mesocarp + epicarp); the fresh mass of the seed with endocarp; the fresh mass of the seed and endocarp separately; the proportions of pulp, seed and endocarp; and the longitudinal and polar diameter of fruits and seeds.
Each sample was weighed on an analytical scale (precision, $\pm 0.01 \mathrm{~g}$ ) and pulped with a scalpel and spatula. In order to measure the dry matter of the pulp, it was checked and placed in an air circulation oven at $65 \pm 5^{\circ} \mathrm{C}$ for 24 hours. Humidity was calculated by finding the difference between wet mass and dry mass and dividing it by wet mass (Moura et al. 2010).

The mass of the seeds was quantified by obtaining the difference (fruit - fresh pulp) and by cracking them in a hand press for the removal and weighing of the seeds. The mass of the endocarp was also determined by difference (endocarp with seed - seed). The longitudinal and polar diameters of fruits and seeds were measured with a manual caliper, and values were expressed in millimeters. The diametric values were distributed in frequency histograms.

We calculated the mean, standard deviation and coefficient of variation, and we showed the minimum and maximum values for each characteristic measured. The biometric data underwent Pearson correlation analysis (r), and its significance was determined using a t-test.

\section{Germination}

The study was conducted in two trials, in which the effectiveness of treatments to overcome dormancy (experiment 1 ) and the effect of seed drying on viability and vigor (experiment 2 ) were evaluated. All seeds had been previously disinfected with alcohol (70\% for 1 minute) and sodium hypochlorite (2\% for 3 minutes) and then washed in distilled water. The determination of moisture content was accomplished through the oven method at $105 \pm 3^{\circ} \mathrm{C}$ for 24 hours (Brasil 2009), with two replicates of six seeds each. Although the structure used in experiments was technically the pyrene (seed with endocarp), the term "seed" will be used hereafter.

In experiment 1, ripe S. romanzoffiana fruits were collected from two clusters from different matrices located in the city of Florianópolis, in the state of Santa Catarina. After harvest, a sample of 400 intact, uninjured fruits was selected from the base, middle and apex of both bunches, then undergoing epicarp and mesocarp extraction in an electric depulper, producing 800 seeds. A sample of 650 seeds was then separated, of which 550 had the fibers that had remain attached to the endocarp removed manually using a scalpel and spatula. Seeds remained in a laboratory environment for four days prior to treatment. In order to evaluate the efficiency of the dormancy prevention method, seeds were divided into six groups to be evaluated with four replicates of 25 seeds each: T1 (perforation of the operculum with tweezers); T2 (perforation of the operculum with tweezers and soaking the seeds in water for 24 hours); T3 (cracking the seeds with a hammer); T4 (subjected to fire for three minutes); T5 (fibers not removed); and control (untreated). The seeds were subjected to germination tests using trays with vermiculite in a germination chamber at $30^{\circ} \mathrm{C}$ on a 12/12-h light/dark cycle. 
For experiment 2, we selected 400 whole, uninjured mature fruits from another bunch harvested in Florianópolis. The fruits underwent electric pulping as in experiment 1. The fibers still adhering to the endocarp were removed manually with a scalpel and spatula. After the withdrawal of the control samples, we separated the sample of recently-harvested seeds with a moisture content of 20.2\% (group T0), and the remaining seeds were dried until reaching a moisture content of $15.5 \%$ (group T1) and 12.7\% (group T2). In the all three groups, we perforated the operculum of the seeds, immersed them in water for 24 hours and subjected them to germination tests with four replicates of 25 seeds each, under the same conditions cited for experiment 1.

For the evaluation of germination, two stages were considered. The first refers to the breaking of the tegument by the radicle which results in radicle protrusion-declared when seeds showed a radicle emission length of at least 1 millimeter-and the second corresponds to the formation of normal seedlings, i.e., those possessed of all structures essential for establishing themselves in the wild (Brasil 2009).

We evaluated the following variables: germination, germination speed index (GSI) - determined according to the formula proposed by Maguire (1962) — and the radicle length at day 35 after radicle protrusion. Counts were made every three days, beginning at radicle protrusion: on days 13 and 17 for experiments 1 and 2, respectively, and continued until days 41 and 79, respectively, at which point the cessation of germination was determined.

The results of germination percentage and GSI are presented according to the two stages of germination considered in data collection: radicle protrusion and formation of normal seedlings. Radicle length is common to both stages, given that it was assessed during a single stage, 35 days after radicle protrusion.

The experimental design was completely randomized with four replications of 25 seeds per treatment. The results of germination percentage were transformed into $\arcsin \sqrt{x} / 100$ and means were compared with Tukey's test at $5 \%$ significance.

\section{Results and discussion}

\section{Biometry}

The measurements for diameter, pulp moisture and proportions of pulp and endocarp varied little. However, values for fruit mass, pulp mass, endocarp mass and seed with endocarp mass, as well as pulp dry mass and seed mass proportion, showed greater variation (Tab. 1).

It is common for palm species to present individual variations for different characteristics, being attributed to, among other factors, environmental differences and genetic variability (Mhanhmad et al. 2011). The size and mass of the seeds may be influenced by the fruit ripening stage, genetic factors and climatic conditions under which the plant develops (Macedo et al. 2009; Batista et al. 2011). Regarding the values for diameter, the distribution of the longitudinal diameter of the fruits was concentrated around 21-22 $\mathrm{mm}$, whereas that of the seeds was concentrated around $19-20 \mathrm{~mm}$. With regard to polar diameter, a greater difference between fruits and seeds can be observed, with fruit measurements predominantly falling between $19 \mathrm{~mm}$ and $20 \mathrm{~mm}$ and seeds in the range of 13-14 mm (Fig. 1). Therefore, fruits and seeds differed more in width than in length. Similar variations in polar diameter of fruits and seeds have also been found in Butia capitata, which showed average values of $27 \mathrm{~mm}$ for fruits and $14 \mathrm{~mm}$ for seeds (Schwartz et al. 2010).

The fruits present a predominantly rounded shape, with an average length of approximately $21 \mathrm{~mm}$, but with variations, similar to those described by Reitz (1974): "Ripe fresh fruit broad-ovoid to short-pyriform and $25 \mathrm{~mm}$ or less in length." Variation in shape also occurs in seeds, in which the elongated form is predominant. In collecting data and observing the correlation data (Table 2), it is clear that the seeds reproduce the shape of the fruit; that is, when the fruits are more elongated or rounded, the seeds also are, while still having the typically smaller polar diameters compared with those of the fruits (Fig. 1B and 1D). This is because the pulp is more concentrated around the central area of the endocarp.

The polar diameter of fruit shows a significant positive linear correlation with fruit mass, pulp mass, seed mass and polar diameter of the seed (Tab. 2). In studies of Butia capitata (Pedron et al. 2004; Moura et al. 2010), significant positive correlations have been found between fruit size and fruit mass; fruit size and seed mass; and fruit size and pulp mass. However, it is of note that in S. romanzoffiana it is only the size of the polar diameter of the fruit that shows a strong positive correlation with the variables mentioned, whereas longitudinal fruit diameter showed a significant positive correlation only with longitudinal seed diameter.

Jerivá fruit, on average, weigh $5.61 \mathrm{~g}$, their mass and size being linearly, positively and significantly correlated and with the size and mass of the seed. This correlation is interesting from the point of view of species propagation, given that in other palms a larger seed size results in a better germination process (Andrade et al. 1996; Martins et al. 2000), indicating the possibility of collecting larger fruits in an attempt to obtain higher rates of germination and vigor (Pedron et al. 2004). The high coefficient of variation found in fruit mass supports the hypothesis of selective collection.

The fruits are composed predominantly of pulp (59.29\%), followed by endocarp (36.73\%) and seed (3.98\%), making the pulp the part of the fruit with the greatest yield. This pulp-to-seed ratio is similar to that of the fruits of Spondias spp., which present an average yield of approximately $55.75 \%$, a characteristic that makes it well-suited to industrialization (Lima et al. 2002). Compared with $E$. oleracea, the fruits of which are known as açaí, the propor- 
Table 1. Biometric parameters for fruits of Syagrus romanzoffiana (Cham.) Glassm., Arecaceae ( $\mathrm{n}=400,50$ fruits from eight infructescences), collected on Santa

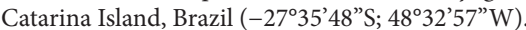

\begin{tabular}{|c|c|c|c|c|c|}
\hline Parameter & mean & deviation & minimum & maximum & CV (\%) \\
\hline \multicolumn{6}{|l|}{ Fruits } \\
\hline Longitudinal diameter (mm) & 21.69 & 1.38 & 19.84 & 23.95 & 6.34 \\
\hline Polar diameter (mm) & 19.66 & 2.18 & 16.51 & 22.84 & 11.1 \\
\hline \multicolumn{6}{|l|}{ Seeds with endocarp } \\
\hline Longitudinal diameter (mm) & 19.82 & 1.24 & 18.46 & 22.17 & 6.27 \\
\hline Polar diameter (mm) & 13.73 & 1.63 & 12.03 & 16.27 & 11.84 \\
\hline Fruit mass (g) & 5.61 & 1.84 & 2.18 & 8.28 & 32.8 \\
\hline Pulp mass (g) & 3.44 & 1.00 & 2.15 & 5.1 & 29.2 \\
\hline Pulp dry mass (g) & 1.14 & 0.38 & 0.75 & 1.74 & 33.4 \\
\hline Pulp moisture (\%) & 66.83 & 1.86 & 65.27 & 71.53 & 2.78 \\
\hline Seed with endocarp mass ( $\mathrm{g}$ ) & 2.33 & 0.58 & 1.65 & 3.18 & 24.81 \\
\hline Endocarp mass (g) & 2.10 & 0.55 & 1.3 & 2.81 & 35.76 \\
\hline Seed mass (g) & 0.23 & 0.08 & 0.16 & 0.36 & 4.65 \\
\hline$\%$ of pulp in fruit & 59.29 & 2.76 & 56.6 & 64.1 & 4.14 \\
\hline$\%$ of seed in fruit & 3.98 & 1.95 & 2.38 & 9.1 & 49.04 \\
\hline$\%$ of endocarp in fruit & 36.73 & 3.08 & 33 & 40.8 & 8.39 \\
\hline
\end{tabular}
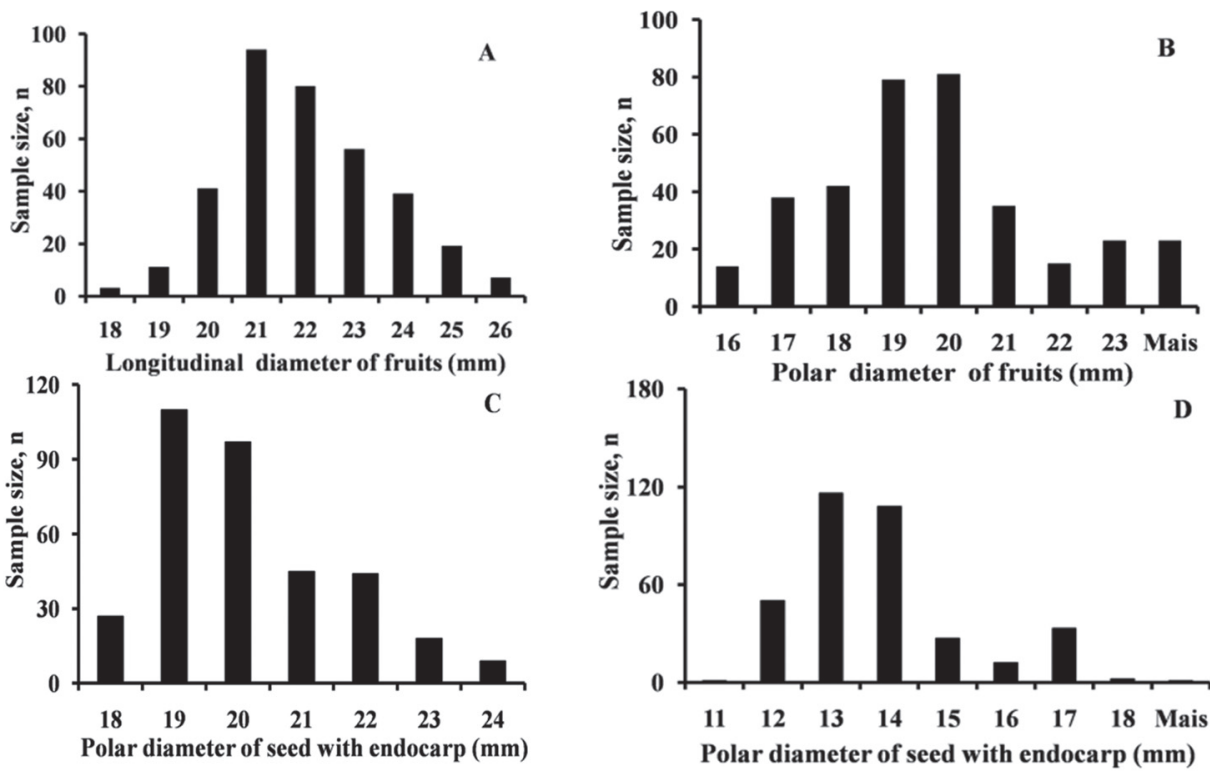

Figure 1. Frequency histograms of the longitudinal and polar diameters of fruits (in A and B, respectively), as well as of the longitudinal and polar diameters of the seeds with endocarp (in C and D, respectively).

tion of pulp obtained from jerivá is much higher: $59.29 \%$ vs. $7.5 \%$ (Rogez 2000).

The pulp obtained from a single jerivá fruit weighed, on average, $3.44 \mathrm{~g}$ and had a high coefficient of variation (\%), ranging from $2.15 \mathrm{~g}$ to $5.01 \mathrm{~g}$, indicating the possibility of selecting fruits with a higher proportion of pulp. Pulp mass showed a significant positive linear correlation with fruit mass and with polar diameter, which is an important fact if the objective is improvement, given that such knowledge facilitates the identification of fruits with more pulp. The moisture content of the pulp is $66.83 \%$, indicating the need for post-harvest care to avoid damage to the physical, chemical and organoleptic characteristics of the fruit (Moura et al. 2010).
We observed one seed per fruit. We also observed seed predation by the larvae of the weevil Revena rubiginosa (Curculionidae), a specific predator of $S$. romanzoffiana (Alves-Costa \& Knogge 2005). Of the eight bunches assessed, five (62\%) showed infestation, and, on average, $24 \%$ of the seeds were predated. Although this is a high rate of seed predation, it did not affect the fruit flesh. We observed only a small scar on epicarp and a small hole in the endocarp, resulting from the exit of $R$. rubiginosa, which continues its cycle in the soil (Alves-Costa \& Knogge 2005), but this aspect interferes very little with maturation or with the integrity of the pulp.

The jerivá seed is small and difficult to extract, because it is attached to the endocarp through a recess which makes its 
Table 2. Pearson coefficient of correlation matrix containing biometric characteristic variables for fruits of Syagrus romanzoffiana (Cham.) Glassm., Arecaceae, collected on Santa Catarina Island, Brazil ( $-27^{\circ} 35^{\prime} 48^{\prime \prime}$; $\left.48^{\circ} 32^{\prime} 57^{\prime \prime} \mathrm{W}\right)$.

\begin{tabular}{|c|c|c|c|c|c|c|c|c|c|c|c|c|c|c|}
\hline & LDF & PDF & LDSE & PDSE & FM & $\mathrm{PM}$ & PDM & $\mathrm{PH}$ & SEM & EM & SM & $\% \mathrm{P}$ & $\% \mathrm{~S}$ & $\% \mathrm{E}$ \\
\hline LDF & 1.00 & & & & & & & & & & & & & \\
\hline PDF & 0.37 & 1.00 & & & & & & & & & & & & \\
\hline LDSE & $0.85^{\star}$ & 0.58 & 1.00 & & & & & & & & & & & \\
\hline PDSE & 0.41 & $0.93^{*}$ & 0.46 & 1.00 & & & & & & & & & & \\
\hline FM & 0.47 & $0.97^{\star}$ & $0.73^{*}$ & $0.85^{\star}$ & 1.00 & & & & & & & & & \\
\hline PM & 0.50 & $0.98^{*}$ & 0.67 & $0.89^{*}$ & $0.96^{\star}$ & 1.00 & & & & & & & & \\
\hline PDM & 0.51 & $0.97^{\star}$ & 0.64 & $0.91^{*}$ & $0.93^{\star}$ & $0.99^{*}$ & 1.00 & & & & & & & \\
\hline PH & -0.33 & -0.41 & -0.15 & -0.52 & -0.74 & -0.37 & -0.47 & 1.00 & & & & & & \\
\hline SEM & 0.69 & $0.91^{*}$ & $0.81^{* *}$ & $0.88^{\star}$ & $0.93^{*}$ & $0.93^{*}$ & $0.93^{*}$ & -0.48 & 1.00 & & & & & \\
\hline EM & 0.64 & $0.90^{*}$ & $0.83^{* *}$ & $0.84^{*}$ & $0.94^{*}$ & $0.90^{*}$ & $0.90^{*}$ & -0.44 & $0.99^{\star}$ & 1.00 & & & & \\
\hline SM & 0.38 & 0.40 & 0.08 & 0.59 & 0.21 & 0.45 & 0.49 & -0.42 & 0.33 & 0.19 & 1.00 & & & \\
\hline$\% \mathrm{P}$ & -0.23 & 0.47 & -0.01 & 0.25 & 0.43 & 0.52 & 0.47 & 0.21 & 0.17 & 0.15 & 0.27 & 1.00 & & \\
\hline$\% \mathrm{~S}$ & 0.13 & -0.43 & 0.13 & -0.18 & -0.54 & -0.32 & -0.27 & -0.17 & -0.35 & -0.48 & $0.67^{* *}$ & -0.19 & 1.00 & \\
\hline$\% \mathrm{E}$ & 0.14 & -0.15 & 0.26 & -0.11 & -0.04 & -0.26 & -0.25 & -0.08 & 0.07 & 0.18 & -0.67 & -0.78 & -0.46 & 1.00 \\
\hline
\end{tabular}

LDF - longitudinal diameter of fruit; PDF - polar diameter of fruit; LDSE - longitudinal diameter of seed with endocarp; PDSE - polar diameter of seed with endocarp; FM - fruit mass; PM - pulp mass; PDM - pulp dry mass; PH - pulp humidity; SEM - seed with endocarp mass; EM - endocarp mass; SM - seed mass; $\% \mathrm{P}-\%$ pulp; $\% \mathrm{~S}-\%$ seed; $\% \mathrm{E}-\%$ endocarp. ${ }^{*} \mathrm{p}<0.05 ;{ }^{* *} \mathrm{p}<0.01$.

removal without damage a near-impossible task. Therefore, we were able to evaluate seed weight but not seed diameter. On average, the seed weighs $0.23 \mathrm{~g}$, a value lower than the approximately 0.5 grams found by Balick (1979).

\section{Germination}

The results of the germination tests performed in experiment 1, as well as GSIs and radicle lengths, are presented for the radicle protrusion and normal seedling stages in Tab. 3 and 4, respectively. The $S$. romanzoffiana seeds subjected to dormancy suppression treatments had a moisture content of $12.7 \%$, which is considered low compared with those of other palm species, such as E. oleracea, which has a reported moisture content of approximately $40 \%$ (Martins et al. 1999a) and 43.4\% (Nascimento et al. 2007), and S. oleracea, with 19.9\% (Batista et al. 2011).

All treatments that produced germination had reduced germination values from the radicle protrusion stage to the normal seedling stage, indicating the formation of abnormal seedlings. The losses were 55\%, 40\%, 15\%, 45\% and $20 \%$ for the control, T1, T2, T4 and T5 groups, respectively. We observe, therefore, that the treatment involving perforated operculum and soaking in water for 24 hours (T2) showed the least loss due to seedling malformation (15\%) and the highest percentage of germination both in the radicle protrusion stage (60\%) and the normal seedling stage (50\%).

The differences in the results obtained for the experiment 1 groups T1 (perforation of the operculum) and T2 (perforation of the operculum and soaking) suggest that the hydration of S. romanzoffiana seeds conducted in T2 was an important factor in the fostering of normal seedling germination, as well as in radicle length and GSI as compared with the other treatments, indicating higher viability and vigor for seedlings soaked in water for 24 hours. Soaking in water has also been shown to be favorable for S. coronata seeds, whose germination rate was found to be directly proportional to the time of soaking, reaching approximately $60 \%$ in 96 hours, with a GSI of 0.58 (Carvalho et al. 2005), as well as for those of Astrocaryum aculeatum, whose rate of germination increased with the progressive increase of the period of immersion in water, reaching values of up to $70 \%$ after nine days of soaking (Ferreira \& Gentil 2006).

Corroborating the results of the $S$. coronata study conducted by Carvalho et al. (2005), we found that the presence of a woody endocarp did not limit the germination of $S$. romanzoffiana, but that soaking in water was fundamental to achieving higher germination rates and vigor. The pulping might also have had a positive influence on viability and vigor, as has been observed in S. oleracea (Matteucci et al. 1995).

Although our S. romanzoffiana seeds had been subjected to dormancy suppression treatments with a moisture content of $12.7 \%$, a level considered lethal for the germination of certain species of palms (Martins et al. 1999a; Martins et al. 1999b; Nascimento et al. 2007), they exhibited a distinctive behavior. In experiment 2 , the response of the group T2 was satisfactory compared with other treatments, despite the 
Table 3. Germination rate, germination speed index and radicle length $(\mathrm{cm})$ during the radicle protrusion stage in the six dormancy suppression treatments for

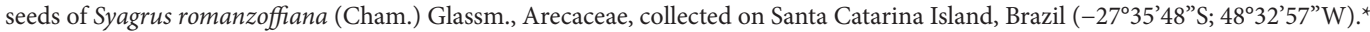

\begin{tabular}{|c|c|c|c|}
\hline \multirow{2}{*}{ Treatment } & \multicolumn{2}{|c|}{ Radicle protrusion } & \multirow{2}{*}{ Radicle length $(\mathrm{cm})$} \\
\hline & Germination rate $(\%)$ & GSI & \\
\hline Control & $45 \mathrm{ab}$ & $0.51 \mathrm{a}$ & $3.72 \mathrm{a}$ \\
\hline Operculum perforated (T1) & $10 \mathrm{c}$ & $0.09 b$ & $3.46 \mathrm{ab}$ \\
\hline Operculum perforated and soaked (T2) & $60 \mathrm{a}$ & $0.11 b$ & $5.1 \mathrm{a}$ \\
\hline Seeds cracked (T3) & $0 \mathrm{~d}$ & $0 \mathrm{c}$ & ob \\
\hline Seeds burned (T4) & $11 \mathrm{c}$ & $0.11 b$ & $3.42 \mathrm{ab}$ \\
\hline Seed fibers not removed (T5) & $35 b$ & $0.39 \mathrm{a}$ & $3.75 \mathrm{a}$ \\
\hline
\end{tabular}

GSI - germination speed index.

*Values in the same column and followed by the same letter do not differ significantly from one another on Tukey's test at $5 \%$ probability.

Table 4. Germination rate, germination speed index and radicle length $(\mathrm{cm})$ during the normal seedling stage in the six dormancy suppression treatments for seeds

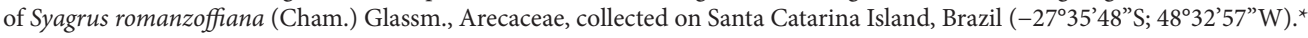

\begin{tabular}{|c|c|c|c|}
\hline \multirow{2}{*}{ Treatment } & \multicolumn{2}{|c|}{ Plants } & \multirow{2}{*}{ Radicle length $(\mathrm{cm})$} \\
\hline & Germination rate $(\%)$ & GSI & \\
\hline Control & $20 \mathrm{~b}$ & $0.14 \mathrm{~b}$ & $3.72 \mathrm{a}$ \\
\hline Operculum perforated (T1) & $4 \mathrm{c}$ & $0.04 \mathrm{c}$ & $3.46 \mathrm{ab}$ \\
\hline Operculum perforated and soaked (T2) & $50 \mathrm{a}$ & $0.40 \mathrm{a}$ & $5.1 \mathrm{a}$ \\
\hline Seeds cracked (T3) & $0 \mathrm{c}$ & od & $0 \mathrm{~b}$ \\
\hline Seeds burned (T4) & $4 c$ & $0.04 \mathrm{~cd}$ & $3.42 \mathrm{ab}$ \\
\hline Seed fibers not removed (T5) & $28 \mathrm{~b}$ & $0.19 \mathrm{~b}$ & $3.75 \mathrm{a}$ \\
\hline
\end{tabular}

GSI - germination speed index.

*Values in the same column and followed by the same letter do not differ significantly from one another on Tukey's test at $5 \%$ probability.

Table 5. Comparison of values for germination rate, germination speed index and radicle length during the radicle protrusion stage of Syagrus romanzoffiana (Cham.) Glassm., Arecaceae, with different humidity rates and treated for suppression of dormancy through operculum perforation and immersion in water for 24 hours.

\begin{tabular}{|c|c|c|c|c|}
\hline \multirow{2}{*}{ Treatment } & \multirow{2}{*}{$\frac{\text { Seed }}{\text { Moisture content }(\%)}$} & \multicolumn{2}{|c|}{ Radicle protrusion } & \multirow{2}{*}{ Radicle length $(\mathrm{cm})$} \\
\hline & & Germination rate $(\%)$ & GSI & \\
\hline T0 & 20.2 & $76 a$ & $0.56 \mathrm{~b}$ & $4.73 a$ \\
\hline $\mathrm{T} 1$ & 15.5 & $67 \mathrm{ab}$ & $0.69 \mathrm{a}$ & $5.76 \mathrm{a}$ \\
\hline $\mathrm{T} 2$ & 12.7 & $60 b$ & $0.11 \mathrm{c}$ & $5.1 \mathrm{a}$ \\
\hline
\end{tabular}

GSI - germination speed index.

*Values in the same column and followed by the same letter do not differ significantly from one another on Tukey's test at $5 \%$ probability.

Table 6. Comparison of values for germination rate, germination speed index and radicle length during the normal seedling stage of Syagrus romanzoffiana (Cham.), Arecaceae, with different humidity rates and treated for suppression of dormancy through operculum perforation and immersion in water for 24 hours.

\begin{tabular}{|c|c|c|c|c|}
\hline \multirow{2}{*}{ Treatments } & \multirow{2}{*}{$\frac{\text { Seed }}{\text { Moisture content }(\%)}$} & \multicolumn{2}{|l|}{ Plants } & \multirow{2}{*}{ Radicle length $(\mathrm{cm})$} \\
\hline & & Germination rate (\%) & GSI & \\
\hline T0 & 20.2 & $64 \mathrm{a}$ & $0.28 b$ & $4.73 \mathrm{a}$ \\
\hline $\mathrm{T} 1$ & 15.5 & $52 \mathrm{a}$ & $0.29 b$ & $5.76 \mathrm{a}$ \\
\hline $\mathrm{T} 2$ & 12.7 & $50 a$ & $0.40 \mathrm{a}$ & $5.1 \mathrm{a}$ \\
\hline
\end{tabular}

GSI - germination speed index.

*Values in the same column and followed by the same letter do not differ significantly from one another on Tukey's test at $5 \%$ probability. 
$12.7 \%$ moisture content, indicating that S. romanzoffiana seeds are tolerant of partial drying. On the basis of this assumption, experiment 2 was conducted by subjecting the seeds to drying and afterward affecting dormancy suppression with perforation of the operculum and soaking in water for 24 hours. (Tab. 5 and 6)

As observed in experiment 1 , there was a reduction in the germination rate during the radicle protrusion stage and normal seedling stage, indicating the formation of abnormal seedlings. For the experiment 2 groups T0, T1 and T2, The losses were $15.8 \%, 22.4 \%$ and $15.5 \%$, respectively.

In the radicle protrusion stage, $S$. romanzoffiana seeds with $12.7 \%$ moisture (experiment 2 group T2) presented lower germination rates and vigor than did those in the other two groups. However, in the normal seedling stage, T2 group seeds showed no significant difference in germination rate and stood out from those in the other two groups in that the GSI was higher. The partial drying of the seeds did not cause a significant reduction in the viability and vigor of $S$. romanzoffiana seeds, the seeds in the experiment 2 groups $\mathrm{T} 1$ and $\mathrm{T} 2$ (moisture content reduced to $15.5 \%$ and $12.7 \%$, respectively) showed germination rates, GSIs and radicle lengths similar to those of the seeds in group T0 (moisture content of $20.2 \%$ ).

The behavior observed in this study for S. romanzoffiana seeds is distinct from that of those of E. oleracea, whose critical moisture content is approximately 30\% and whose lethal range is between $17.4 \%$ and $18.9 \%$ (Martins et al. 1999a), or $15.1 \%$ (Nascimento et al. 2007), as well as from that of those of E. espiritosantensis, which showed a reduction in germination and vigor beginning at moisture levels ranging from $40.7 \%$ to $51.4 \%$, and total mortality of seeds at moisture contents between $13.4 \%$ and $15.8 \%$ (Martins et al. 1999b). However, seeds of I. uruguensis, for example, although recalcitrant, can be subjected to partial drying, from $58 \%$ to $49 \%$ moisture content, without detriment to their physiological potential (Bilia et al. 1998). Ellis et al. (1990) suggested the possibility of a third category of classification, intermediate, for seeds that exhibit neither typically orthodox nor recalcitrant storage behavior. The results of the present study suggest that $S$. romanzoffiana seeds are tolerant of partial drying. Further studies with controlled dehydration are needed in order to determine the critical and lethal levels, as well as the ideal storage conditions, for seeds of the species.

The genetic component might influence tolerance to dehydration (Elllis et al. 1991) as well as germination and vigor (Martins et al. 1999a). Therefore, the variations found in the biometric characteristics of the fruits of S. romanzoffiana-especially in terms of the fruit and seed masses-should be considered in future projects, because such variations indicate the possibility of differentiation among lots. The formation of lots that are more homogeneous can contribute both to testing dehydration tolerance behavior and to determining the influence of seed size on the germination process, given that, in some palms, heavier and larger seeds provide more uniformity, viability and vigor (Andrade et al. 1996; Martins et al. 2000). Because S. romanzoffiana seed size is positively and significantly correlated with the mass and size of the fruit, the formation of lots can be planned and initiated in the field through selective fruit collection.

\section{Conclusions}

As evidenced by our data, S. romanzoffiana presents variation in fruit, pulp and seed mass, which can be exploited for breeding projects and should be considered in the formation of seed lots that are more homogeneous. Seed size is correlated with fruit size, a characteristic that enables differentiation in fruit collection. Fruits with higher polar diameters present greater pulp mass, allowing the identification of fruits with more pulp through shape. The perforation of the operculum followed by soaking in water for 24 hours results in greater germination and more vigorous seedlings. Partial drying of seeds has no apparent negative effect on viability and vigor, suggesting tolerance to water loss.

\section{References}

Alves-Costa, C.P. \& Knogge, C. 2005. Larval competition in weevils Revena rubiginosa (Coleoptera: Curculionidae) preying on seeds of the palm Syagrus romanzoffiana (Arecaceae). Naturwissenschaften 92: 265-268.

Andrade, A.C.S.; Venturi, S. \& Paulilo, M.T.S. 1996. Efeito do tamanho das sementes de Euterpe edulis Mart. sobre a emergência e crescimento inicial. Revista Brasileira de Sementes 18(2): 225-231.

Balick, M.J. 1979. Amazon oil palms of promise: a survey. Economic Botany 33(1): 11-28.

Batista, G.S.; Costa, R.S.; Gimenes, R.; Pivetta, K.F.L. \& Môro, F.V. 2011. Aspectos morfológicos dos diásporos e das plântulas de Syagrus oleracea (Mart.) Becc - Arecaceae. Comunicata Scientiae 2(3): 170-176.

Bilia, D.A.C.; Marcos Filho, J. \& Novembre, A.D.L.C. 1998. Conservação da qualidade fisiológica de sementes de Ingá uruguensis Hook Et Arn. Revista Brasileira de Sementes 20(1): 48-54.

Brasil. 2009. Ministério da Agricultura, Pecuária e Abastecimento. Regras para análise de sementes. Ministério da Agricultura, Pecuária e Abastecimento. Secretaria de Defesa Agropecuária. Brasília, Mapa/ ACS.

Broschat, T.K. 1994. Palm seed propagation. Acta Horticulturae 360: 141-147.

Carvalho, N.O.S.; Pelacani, C.R.; Rodrigues, M.O. De S. \& Crepaldi, I.C. 2005. Uso de substâncias reguladoras e não-específicas na germinação de sementes de licuri (Syagrus coronata (Mart.) Becc.). Sitientibus Série Ciências Biológicas 5(1): 28-32.

Carvalho, P.E.R. 2006. Espécies Árboreas Brasileiras. Brasília: Embrapa Informação Tecnológica.

Cruz, E. D. \& Carvalho, J.E.U. 2003. Biometria de frutos e germinação de sementes de Couratari stellata A.C. Smith (Lecythidaceae). Acta Amazonica 33(3): 389:398.

Cruz, E.D.; Martins, F.O. \& Carvalho, J.E.U. 2001. Biometria de frutos e sementes e germinação de jatobá-curuba (Hymenaea intermédia Ducke, Leguminosae - Caesalpinioideae). Revista Brasileira de Botânica 24(2): 161-165

Downer, J. \& Hodel, D. 2001.The effects of mulching on establishment of Syagrus romanzoffiana (Cham.) Becc., Washingtonia robusta $\mathrm{H}$. Wendl. and Archontophoenix cunninghamiana (H. Wendl.) H. Wendl. \& Drude in the landscape. Scientia Horticulturae 87: 85-92. 
Ellis, R.H.; Hong, T.D. \& Roberts, E.H. 1990. An intermediate category of seed storage behavior. Journal of Experimental Botany 41: $1167-1174$

Ellis, R.H.; Hong, T.D.; Roberts, E.H. \& Soetisna, U. 1991. Seed storage behaviour in Elaeis guineensis. Seed Science Research 1: 99-104.

Ferreira, S.A.N. \& Gentil, D.F.O. 2006. Extração, embebição e germinação de sementes de tucumã (Astrocaryum aculeatum). Acta Amazônica 36(2): 141-146.

Genini, J.; Galetti,M. \& Morellato, L.P.C. 2009. Fruiting phenology of palms and trees in an Atlantic rainforest land-bridge island. Flora 204: 131-145.

Lam, S.H.; Chen, J.M.; Kang, C.J.; Chen, C.H. \& Lee, S.S. 2008. aGlucosidase inhibitors from the seeds of Syagrus romanzoffiana. Phytochemistry 69: 1173-1178.

Lima, E.D.P. De A.; Lima, C.A. De A.; Aldrigue, M.L. \& Gondim, P.J.S. 2002. Caracterização física e química dos frutos da umbu-cajazeira (Spondias spp) em cinco estádios de maturação, da polpa congelada e néctar. Revista Brasileira de Fruticultura 24(2): 338-343.

Lorenzi, H. 2002. Árvores brasileiras, manual de identificação e cultivo de plantas arbóreas nativas do Brasil. 4 ed. Nova Odessa: Plantarum.

Macedo, M.C. De.; Scalon, S. De P.Q.; Sari, A.P.; Scalon Filho, H.; Rosa, Y.B.C.J. \& Robaina, A.D. 2009. Biometria de frutos e sementes e germinação de Magonia pubescens St.Hil (Sapindaceae). Revista Brasileira de Sementes 31 (2): 202-211

Maguire, J.D. 1962. Speed of germination-aid in selection and evaluation for seedling emergence and vigour. Crop Science 2(1): 176-177.

Martins, C.C.; Nakagawa, J. \& Bovi, M.L.A. 1999a. Tolerância à dessecação de sementes de palmito-vermelho (Euterpe espiritosantensis Fernandes). Revista Brasileira de Botânica 22(3): 391-396.

Martins, C.C.; Nakagawa, J.; Bovi, M.L.A. \& Stanguerlim, H. 1999b. Teores de água crítico e letal para sementes de açaí (Euterpe oleracea Mart.). Revista Brasileira de Sementes 21(1): 125-132.

Martins, C.C., Nakagawa, J. \& Bovi, M.L.A. 2000. Influência do peso das sementes de palmito - vermelho (Euterpe espiritosantensis Fernandes) na porcentagem e na velocidade de germinação. Revista Brasileira de Sementes 22(3): 47-53.
Matteuci, M.B.A. De.; Guimarães, N.N.R.; Duarte. J.B. \& Tiveron Filho, D. 1995. Determinação do melhor tratamento para superação de dormência em guariroba (Syagrus oleracea (Mart.) Becc. Anais da Escola Agronômica e Veterinária 2: 149-153.

Mhanhmad, S.; Leewanish, P.; Punsuvon, V.\& Srinives, P. 2011. Seasonal effects on bunch components and fatty acid composition in Dura oil palm (Elaeis guineensis). African Journal of Agricultural Research 6(7): 1835-1843.

Moura, R.C., Lopes, P.S.N., Brandão Junior, D.S., Gomes, J.G. \& Pereira, M.B. 2010. Fruit and seed biometry of Butia capitata (Mart.) Beccari (Arecaceae), in the natural vegetation of the North of Minas Gerais, Brazil. Biota Neotropical 10(2): 415-419.

Nascimento, W.M.O. Do.; Novembre, A.D. Da L.C. \& Cicero, S.M. 2007. Conseqüências fisiológicas da dessecação em sementes de açaí (Euterpe oleracea Mart.). Revista Brasileira de Sementes 29(2): 38-43.

Negreiros, G.F.; Perez, S.C.J.G.A. 2004. Resposta fisiológica de sementes de palmeiras ao envelhecimento acelerado. Pesquisa agropecuária brasileira 39(4): 391-396

Pedron, F. De A.; Menezes, J.P. \& Menezes, N.L. 2004. Parâmetros biométricos de fruto, endocarpo e semente de butiazeiro. Ciência Rural 34(2): 585-586.

Reitz, P. R. 1974. Flora Ilustrada Catarinense. Palmeiras. Itajaí: Herbário Barbosa Rodrigues.

Rogez, H. 2000. Açaí: Preparo, Composição e Melhoramento da Conservação. Belém: EDUFPA.

Schwartz, E.; Fachinello, J.C.; Barbieri, R.L. \& Silva, J.B. da. 2010. Avaliação de populações de Butia capitata de Santa Vitória do Palmar. Revista Brasileira de Fruticultura 32(3): 736-745.

Smiderle, O.J.; Mourão Junior, M. \& Sousa, R. de C.P. de. 2005. Tratamentos pré-germinativos em sementes de acácia. Revista Brasileira de Sementes 27(1): 78-85.

Torres, I.C. 2002. Estudo sobre propagação por semente com jerivá (Syagrus romanzoffiana (Cham.) Glassman.). Ensaio de Aferição de Metodologia de Análise entre Laboratórios de Sementes da Rede Semente Sul. Florianópolis. 